\title{
RIM2a/RBP2/ $\beta$-subunit co-expression stabilizes slow Cav1.3 channel inactivation to improve auditory perception
}

\author{
Emilio Carbone ${ }^{1}$ (D)
}

Received: 3 December 2019 / Revised: 3 December 2019 / Accepted: 4 December 2019/Published online: 17 December 2019

(C) Springer-Verlag GmbH Germany, part of Springer Nature 2019

\section{Introduction}

Cav1.3 channels are voltage-gated L-type $\mathrm{Ca}^{2+}$ channels that are highly expressed in cochlear inner hair cells (IHCs) [1]. The channels are localized predominantly in the active zones of presynaptic ribbons of IHCs and carry most of the $\mathrm{Ca}^{2+}$ currents (>90\%) required for transforming sound-evoked depolarization into graded $\mathrm{Ca}^{2+}$-dependent glutamate release at the IHC-auditory nerve synapse [3]. Cav1.3 channels activate at relatively negative potentials and exhibit fast activation and very slow inactivation kinetics $[5,7,12]$. In this way, they allow fast and sustained $\mathrm{Ca}^{2+}$ signals in a broad range of voltages, making them suitable to transform sound-evoked IHC receptor potential into glutamate release at the postsynaptic ending of auditory nerves. While fast activation and a negative activation voltage range are typical hallmarks of Cav1.3 channels in a variety of excitable cells $[3,7,8]$, their slow inactivation kinetics is unique to IHCs. As other voltagegated $\mathrm{Ca}^{2+}$ channels, Cav1.3 channel inactivation is both $\mathrm{Ca}^{2+}$ (CDI)- and voltage (VDI)-dependent [2]. CDI is fast and calmodulin $(\mathrm{CaM})$-dependent. $\mathrm{CaM}$, activated by $\mathrm{Ca}^{2+}$, binds to the $\mathrm{N}$ - and $\mathrm{C}$-terminal motifs of the pore-forming $\alpha 1$-subunit and inactivates the open channel. VDI of Cav1.3 channels is the predominant inactivation mechanism and is measured by replacing $\mathrm{Ca}^{2+}$ with $\mathrm{Ba}^{2+}$ to prevent $\mathrm{Ca}^{2+}$-dependent $\mathrm{CaM}$ activation [2]. In IHCs, VDI is ultra-slow while CDI is nearly absent since mediated by $\mathrm{CaBP} 2$, a CaM-like $\mathrm{Ca}^{2+}$-binding protein abundantly expressed in IHCs that prevents CaMmediated CDI [11].

This article is a commentary to the original article https://doi.org/10.1007/ s00424-019-02338-4

Emilio Carbone

emilio.carbone@unito.it

1 Department of Drug Science, Lab of Cell Physiology and Molecular Neuroscience, University of Torino, Torino, Italy
Although it is known that accessory $\beta$-subunits and other intracellular proteins can modify Cav1.3 channel inactivation [9], the underlying molecular components regulating the slow VDI in IHCs are not yet fully identified. For instance, the major $\beta$-isoforms expressed in IHCs ( $\beta 2 \mathrm{a}$ and $\beta 2 \mathrm{e})$ are known to slow VDI to a greater degree than $\beta 3$, which has been consistently detected in IHCs [9]. Proteins of the presynaptic active zone, such as bassoon, RIM, and RIM-binding proteins (RBPs) [6] are also able to slow VDI of Cav1.3 in IHC. These proteins favor Cav1.3 channels positioning close to the readily releasable synaptic vesicles at the IHC ribbon synapse and can therefore tightly regulate Cav1.3 channel inactivation kinetics. This hypothesis is supported by previous observation by Joerg Striessnig laboratory [4] that RIM2 $\alpha$ binding to the $\beta 3$-subunit stabilizes slow Cav1.3 VDI but not to the extent as observed in IHCs.

In this issue, the Joerg Striessnig group (Ortner et al., 2020) shows with impressive details that co-expression of RBP2 together with RIM2 $\alpha$ in heterologous tsA-201 cells dramatically slows the VDI of the Cav $1.3 \mathrm{~L} / \beta 3$ channel complex, mimicking the ultra-slow $\mathrm{Ca}^{2+}$ current inactivation kinetics existing in IHCs [10]. Figure 1 (left) summarizes how VDI inactivation of Cav1.3L currents become progressively slower by co-expressing $\beta 3$ or $\beta 2$ a with RIM2a and RBP2a to mimic closely the slow VDI in adult mouse IHC. This occurs due to the unique properties of RBP2a that can bind through distinct SH3 domains simultaneously to the $\beta$-subunits associated to RIM $2 \alpha$ and to the $\mathrm{C}$ terminus of long Cav1.3 splice variants (Fig. 1, right). This effect requires the presence of the Cav1.3 long $\mathrm{C}$ terminus splice variant, which contains the RBP2 interaction site and occurs both in the presence $\beta 2 \mathrm{a}(\beta 2 \mathrm{e})$ or $\beta 3$ subunits. In conclusion, Ortner et al. 2020 show clearly that the slow VDI of Cav1.3 channels, mimicking the ultra-slow inactivation in IHC, is effectively controlled by interactions with proteins of the presynaptic active zone (RIM $2 \alpha$ and RBP2) in association with $\beta 2$ or $\beta 3$-subunits in a Cav1.3 splice variant-dependent manner. 


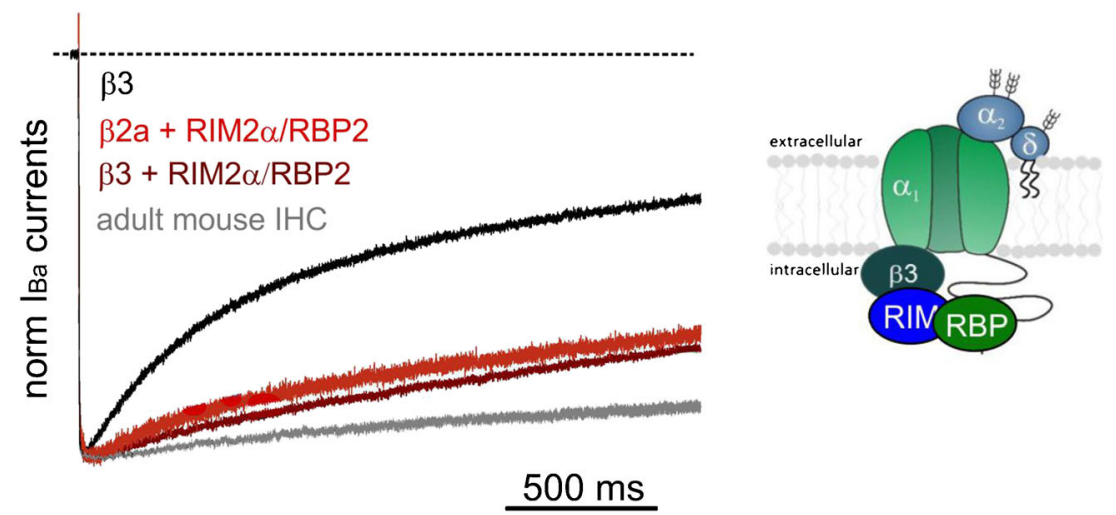

Fig. 1 Progressively slower $\mathrm{I}_{\mathrm{Ba}}$ inactivation of Cav1.3L co-expressed in tsA-201 cells with $\beta 3$ and $\beta 2 \mathrm{a}$-subunits and RIM2 $\alpha /$ RBP2 proteins. (Left) Normalized mean $\mathrm{Ba}^{2+}$ currents $\left(15 \mathrm{mM} \mathrm{Ba}^{2+}\right)$ of Cav1.3L/ $\alpha 2 \delta 1$ with $\beta 3$ (black), $\beta 3 /$ RIM2 $\alpha /$ RBP2 (dark red), or $\beta 2 a / R I M 2 \alpha /$ $\mathrm{RBP} 2$ (red) recorded during the first $2 \mathrm{~s}$ of a depolarization to reach

\section{References}

1. Brandt A, Striessnig J, Moser T (2003) CaV1.3 channels are essential for development and presynaptic activity of cochlear inner hair cells. J Neurosci 23:10832-10840

2. Dick IE, Tadross MR, Liang H, Tay LH, Yang W, Yue DT (2008) A modular switch for spatial $\mathrm{Ca} 2+$ selectivity in the calmodulin regulation of $\mathrm{CaV}$ channels. Nature 451:830-834

3. Engel J, Michna M, Platzer J, Striessnig J (2002) Calcium channels in mouse hair cells: function, properties and pharmacology. Adv Otorhinolaryngol 59:35-41

4. Gebhart M, Juhasz-Vedres G, Zuccotti A, Brandt N, Engel J, Trockenbacher A, Kaur G, Obermair GJ, Knipper M, Koschak A, Striessnig J (2010) Modulation of Cav1.3 Ca2+ channel gating by Rab3 interacting molecule. Mol Cell Neurosci 44:246-259

5. Hering S, Zangerl-Plessl EM, Beyl S, Hohaus A, Andranovits S, Timin EN (2018) Calcium channel gating. Pflugers Archiv Eur J Physiol 470:1291-1309

6. Hibino H, Pironkova R, Onwumere O, Vologodskaia M, Hudspeth AJ, Lesage F (2002) RIM binding proteins (RBPs) couple Rab3interacting molecules (RIMs) to voltage-gated $\mathrm{Ca}(2+)$ channels. Neuron 34:411-423

7. Koschak A, Reimer D, Huber I, Grabner M, Glossmann H, Engel J, Striessnig J (2001) Alpha 1D (Cav1.3) subunits can form L-type $\mathrm{Ca} 2+$ channels activating at negative voltages. J Biol Chem 276: 22100-22106 maximal current amplitude. For comparison is shown the mean $\mathrm{Ba}^{2+}$ current recorded in mature mouse IHCs (gray). (Right) Schematic illustration of the molecular components ( $\beta 3$, RIM, RBP) co-expressed with Cav1.3L (modified from Figs. 8 and 13 of ref. 10; Ortner et al. 2020)

8. Lingle CJ, Martinez-Espinosa PL, Guarina L, Carbone E (2018) Roles of $\mathrm{Na}(+), \mathrm{Ca}(2+)$, and $\mathrm{K}(+)$ channels in the generation of repetitive firing and rhythmic bursting in adrenal chromaffin cells. Pflugers Archiv: Eur J Physiol 470:39-52

9. Neef J, Gehrt A, Bulankina AV, Meyer AC, Riedel D, Gregg RG, Strenzke N, Moser T (2009) The Ca2+ channel subunit beta2 regulates $\mathrm{Ca} 2+$ channel abundance and function in inner hair cells and is required for hearing. J Neurosci 29:10730-10740

10. Ortner NJ, Pinggera A, Hofer NT, Brandt N, Raffeiner A, Vilusic K, Lang I, Blum K, Obermair GG, Stefan E, Engel J, and Striessnig J. RBP2 stabilizes slow Cav1.3 Ca2+ channel inactivation properties of cochlear inner hair cells. Pflugers Archiv: Eur J Psysiol. 11ttps:// doi.org/10.1007/s00424-019-02338-4

11. Picher MM, Gehrt A, Meese S, Ivanovic A, Predoehl F, Jung S, Schrauwen I, Dragonetti AG, Colombo R, Van Camp G, Strenzke $\mathrm{N}$, Moser T (2017) $\mathrm{Ca}(2+)$-binding protein 2 inhibits $\mathrm{Ca}(2+)$-channel inactivation in mouse inner hair cells. Proc Natl Acad Sci U S A 114:E1717-e1726

12. Zamponi GW, Striessnig J, Koschak A, Dolphin AC (2015) The physiology, pathology, and pharmacology of voltage-gated calcium channels and their future therapeutic potential. Pharmacol Rev 67: $821-870$

Publisher's note Springer Nature remains neutral with regard to jurisdictional claims in published maps and institutional affiliations. 